\title{
25. THE RESPONSE OF BACTERIAL POPULATIONS TO SAPROPELS IN DEEP SEDIMENTS OF THE EASTERN MEDITERRANEAN (SITE 969) ${ }^{1}$
}

\author{
B.A. Cragg, ${ }^{2}$ K.M. Law, ${ }^{2}$ A. Cramp, ${ }^{3}$ and R.J. Parkes ${ }^{2}$
}

\begin{abstract}
Sediment samples were obtained from 36 depths between the near-surface to almost 100 mbsf (meters below seafloor) at Site 969, south of Crete. Bacterial populations were determined by the acrinine orange direct count technique. The bacterial profile agreed with a general relationship between sediment depth and bacterial concentration previously obtained from a range of different marine sites. Bacterial populations decreased from a near-surface value of $7.76 \times 10^{8} \mathrm{cells} / \mathrm{cm}^{3}$ to $1.0 \times 10^{6}$ cells/ $\mathrm{cm}^{3}$ by 97.79 mbsf. Dividing and divided cell numbers roughly paralleled total bacterial numbers representing $\sim 9.9 \%$ of the total population. At two depths, sapropels were specifically sampled in duplicate and enumeration suggested that bacterial populations within sapropels were homogeneous. Two additional sapropels were also encountered by chance. The data strongly indicated an active and probably growing bacterial population within the sapropels because:

1. Bacterial populations were considerably, and significantly, greater than those in adjacent nonsapropel sediment layers

2. There were locally high TOC concentrations and abundant electron acceptors (sulfate).

3. Evidence of postburial bacterial sulfate reduction activity was supported by independent sulfur isotope data.

4. Dividing bacterial cells were present.
\end{abstract}

These results demonstrate the surprising ability of 4.7 Ma organic matter to continue to provide energy for bacterial populations during burial, and this supports the global presence of a deep bacterial biosphere in marine sediments.

\section{INTRODUCTION}

The presence of a deep bacterial biosphere in marine sediments has now been confirmed by a large amount of work, primarily on Ocean Drilling Program (ODP) sediments (Whelan et al., 1986; Tarafa et al., 1987; Parkes et al., 1990, 1993, 1994, 1995; Cragg, 1994; Cragg et al., 1990, 1992, 1995a, 1995b, 1996, 1997; Cragg and Parkes 1994; Cragg and Kemp, 1995), and recent work indicates a bacterial presence in basaltic basement rocks (Furnes et al., 1996; Giovannoni et al., 1996). The depth profile of sediment bacteria is remarkably consistent across different oceans and shows population sizes of $\sim 9 \times 10^{8}$ cells $/ \mathrm{cm}^{3}$ at the near surface decreasing exponentially to $\sim 1.5 \times 10^{6}$ cells $/ \mathrm{cm}^{3}$ at $500 \mathrm{mbsf}$. In near-surface marine sediments, bacteria play a central role in the degradation and selective preservation of organic matter and are thus intimately involved in biogeochemical cycling of elements (Jørgensen, 1983; Novitsky and Karl, 1986; Jørgensen et al., 1990; Parkes et al., 1993). At greater depths, geochemical evidence has indicated that bacterial populations remain active (Krumbein, 1983), and more recently low levels of bacterial activity have been demonstrated to $500 \mathrm{mbsf}$ in the Japan Sea (Cragg et al., 1992; Getliff et al., 1992; Parkes et al., 1994).

Sediment cores from the Mediterranean Sea contain numerous dark bands that are rich in organic carbon and contain above average amounts of pyrite (Rohling, 1994). These layers, called sapropels, are characteristic of silled marginal seas and seem to have occurred in response to significant changes in climate, circulation, and biogeochemical cycling (Emeis, Robertson, Richter, et al., 1996). A number of models exist to explain sapropel formation, from isolation and subsequent anoxia of deep bottom water, resulting in enhanced organic carbon preservation (Vergnaud-Grazzini et al., 1986),

${ }^{1}$ Robertson, A.H.F., Emeis, K.-C., Richter, C., and Camerlenghi, A. (Eds.), 1998. Proc. ODP, Sci. Results, 160: College Station, TX (Ocean Drilling Program).

${ }^{2}$ Department of Geology, University of Bristol, Bristol, BS8 1RJ, United Kingdom. b.cragg@bristol.ac.uk

${ }^{3}$ Department of Earth Sciences, University of Wales, Cardiff, P.O.Box 914, Cardiff, CF1 3YE, United Kingdom. through increased local organic carbon production (Müller and Suess, 1979), to anti-estuarine circulation combined with influxes of freshwater from the effects of African monsoons on the Nile River and severely reduced evaporation rates (Cramp et al., 1988; Rohling, 1994). Regardless of their method of formation, sapropels represent a locally significant amount of buried organic carbon to which sediment bacteria have had access for some millions of years. The aim of this investigation was to assess the effects of very high levels of buried organic carbon encountered in these sapropels on in situ deepsediment bacterial populations.

\section{MATERIALS AND METHODS Site Description}

Site 969 is located on the Mediterranean Ridge $\sim 120 \mathrm{~km}$ south of Crete $\left(33^{\circ} 50.466^{\prime} \mathrm{N}, 2^{\circ} 52.980^{\prime} \mathrm{E}\right)$ in water $2202 \mathrm{~m}$ deep (Emeis, Robertson, Richter, et al., 1996). The Mediterranean Ridge ( $150 \mathrm{~km}$ wide) separates the Ionian Basin in the west from the Levantine Basin in the east and is believed to be a subduction complex formed by the scraping of sediments from the subducting African plate (Dewey et al., 1973). An unusual feature of the Mediterranean Ridge is the presence of evaporitic deposits of uncertain composition at a depth of 100-400 mbsf, which may influence pore-water chemistry and sediment diagenesis (Emeis, Robertson, Richter, et al., 1996). Surface sediment temperature was $\sim 14^{\circ} \mathrm{C}$, and the geothermal gradient was estimated at $8^{\circ} \mathrm{C} / \mathrm{km}$. Sedimentation rates vary considerably with depth $(6-86 \mathrm{~m} / \mathrm{m} . \mathrm{y}$.) and average $\sim 23 \mathrm{~m} / \mathrm{m}$.y. This site contains $\sim 80$ sapropel beds to $116 \mathrm{mbsf}$, which vary in thickness between 1 and 46 cm (Emeis, Robertson, Richter, et al., 1996).

\section{Shipboard Handling}

A series of $36,1-\mathrm{cm}^{3}$ sediment samples were removed from core sections of Hole 969B between 0 and 97.8 mbsf. Immediately after a core was cut into $1.5-\mathrm{m}$ sections on the outside catwalk, a thin layer of sediment was removed from the section end using a sterile scalpel 
to expose an uncontaminated surface. A $1-\mathrm{cm}^{3}$ sample was then taken with a sterile (autoclaved) 5 -mL syringe from which the luer end had been removed. The sample was ejected directly into a tared serum vial containing $9 \mathrm{~mL}$ of filter sterilized $(0.2 \mu \mathrm{m}) 4 \%$ formaldehyde in artificial seawater. On two occasions, where a cut passed through a sapropel (at 19.9 and 46.9 mbsf with sapropels $4 \mathrm{~cm}$ and $8 \mathrm{~cm}$ thick, respectively), a single sample was taken from each of the adjacent section ends to assess homogeneity of bacterial populations within a sapropel.

\section{Laboratory Handling \\ Direct Microscopic Observations}

Acridine orange staining and microscopic observations were based on the general recommendations of Fry (1988). Fixed samples were vortex mixed, and a 2.5 to $15 \mu \mathrm{L}$ subsample was added to $10 \mathrm{~mL}$ of $2 \%$ filter-sterilized $(0.1 \mu \mathrm{m})$ formaldehyde in artificial seawater. Acridine orange $(50 \mu \mathrm{L})$ was added to give a final concentration of 5 $\mathrm{mg} / \mathrm{L}$. After $3 \mathrm{~min}$, the solution was filtered through a $25-\mathrm{mm}$ Nucleopore black polycarbonate membrane (Costair, High Wycombe, U.K.) of $0.2-\mu \mathrm{m}$ pore size. The filter was rinsed with a further $10 \mathrm{~mL}$ of $2 \%$ filter-sterilized formaldehyde in artificial seawater and mounted in a minimum of paraffin oil under a cover slip. Three replicate filters were prepared from each sample to minimize the variance of the counts (Kirchman et al., 1982). Where 95\% confidence limits of the mean count exceeded $0.5 \log _{10}$ units, further replicate filters were prepared. A minimum of 200 fields of view were counted.

The mounted membrane filters were viewed under incident illumination with a Zeiss Axioskop microscope fitted with a 50-W mercury vapor lamp, a wide-band interference filter set for blue excitation, a $100 \times$ (numerical aperture $=1.3$ ) Plan Neofluar objective lens, and $10 \times$ eyepieces. Bacterially shaped green and red fluorescing objects were counted. Cells' On or Off particles were counted separately, and the numbers of those on particles doubled in the final calculations to account for cells hidden from view by particles (Goulder, 1977). Dividing cells (those with a clear invagination) and divided cells (pairs of cells of identical morphology) were also counted. The detection limit for bacterial cells was estimated as $1 \times 10^{5}$ cells $/ \mathrm{cm}^{3}$ (Cragg and Parkes, 1994).

\section{RESULTS AND DISCUSSION}

Bacterial populations were detected at all depths sampled (Fig. 1). Total bacterial numbers were high at the near surface $\left(9.79 \times 10^{8}\right.$ cells $/ \mathrm{cm}^{3}$ at $0.025 \mathrm{mbsf}$ ) and decreased rapidly to $1.1 \times 10^{6} \mathrm{cells} / \mathrm{cm}^{3}$ by 11.89 mbsf, representing a $>99.8 \%$ decrease in cell numbers. Thereafter, with some notable exceptions, bacterial populations remained relatively constant to our deepest sample at $97.79 \mathrm{mbsf}$ (1.0 $\times 10^{6}$ cells $\left./ \mathrm{cm}^{3}\right)$. This initial rapid decrease in bacterial population size $(\sim 43 \% / \mathrm{m}$ to $11.89 \mathrm{mbsf})$ followed by a very gradual decrease ( $1.8 \% / \mathrm{m}$ to $97.89 \mathrm{mbsf}$ ) has been observed at other ODP sites, particularly in the similarly organic-rich Santa Barbara Basin (Cragg et al., 1995a), but also elsewhere in the Pacific Ocean (Cragg et al., 1990, 1992; Parkes et al., 1990; Cragg, 1994; Cragg and Kemp, 1995). The depth at which this change occurs varies between sites and the reasons for such a marked change remain unclear.

Dividing and divided cells (DDC) were present in all but the deepest sample (Fig. 1), and they correlated closely with the total count $(R$ $=0.689 ; N=36 ; P \gg>0.002$ ) representing $\sim 9.9 \%$ of the total population in each sample. This strong relationship has been observed frequently at other ODP sites (Cragg et al., 1990, 1992; Parkes et al., 1990; Cragg, 1994; Cragg and Kemp, 1995). Near surface numbers were $5.3 \times 10^{7}$ cells $/ \mathrm{cm}^{3}$, which decreased rapidly to $1.0 \times 10^{5}$ cells/ $\mathrm{cm}^{3}$ by 11.89 mbsf. Below this depth DDC remained relatively constant at $3.5 \times 10^{5}$ cells $/ \mathrm{cm}^{3}, 2.3-5.5 \times 10^{5}$ cells $/ \mathrm{cm}^{3}$ (mean and $95 \%$

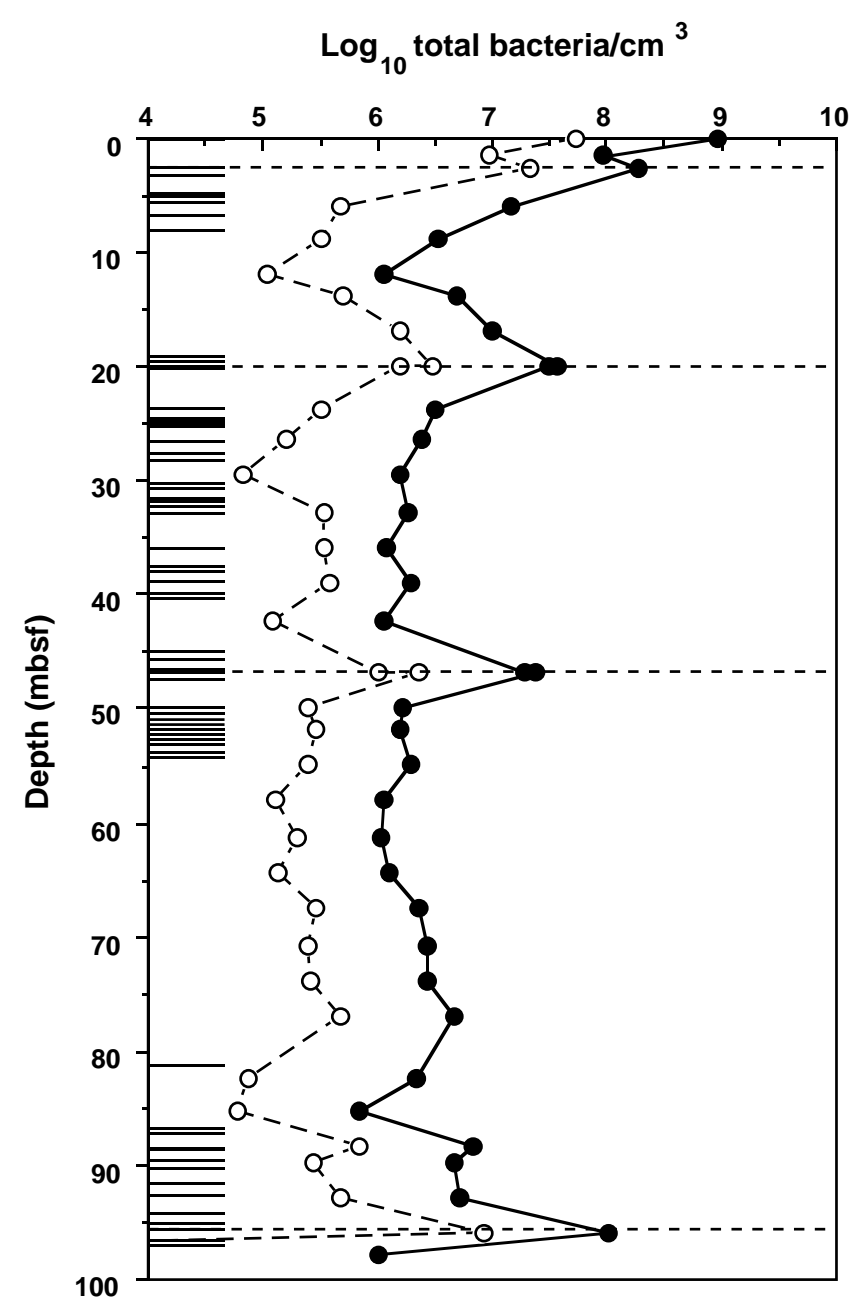

Figure 1. Depth distribution of total bacteria (solid circles) and dividing/ divided cells (open circles) at Hole 969B using the acridine orange direct count (AODC) technique. Average variance for sample enumerations in this data set was $0.012 \log _{10}$ units. This produced an average $95 \%$ confidence limits of $0.251 \log _{10}$ units (range $0.055-0.452$ ). Horizontal lines on the yaxis indicate the presence of sapropels.

confidence limits, respectively), except for increases associated with sapropels. The lack of any DDC in the deepest sample was unexpected, although, as this sample had the second lowest total bacterial population at $1 \times 10^{6}$ cells $/ \mathrm{cm}^{3}$, any DDC count was likely to be at, or near, the detection limit. Although the proportion of dividing cells can not be used to calculate growth rates, the presence of dividing cells can provide an index of growth and hence population viability (Getliff et al., 1992), the presence of significant numbers of bacteria involved in cell division throughout most of the core is indicative of active rather than dormant or senescent populations.

The two planned sapropel samples were at 19.9 and $46.9 \mathrm{mbsf}$. Two additional sapropel samples were obtained serendipitously at 2.72 and $95.89 \mathrm{mbsf}$ (Fig. 1). Unlike the planned samples, these were only single samples. Cell numbers for the sapropel at 19.89-19.91 mbsf were 3.68 and $3.1 \times 10^{7}$ cells $/ \mathrm{cm}^{3}$ and for the sapropel at $46.89-$ $46.91 \mathrm{mbsf}$ were 2.0 and $2.4 \times 10^{7}$ cells $/ \mathrm{cm}^{3}$. Two sample $t$-tests performed separately at each of the two sediment depths indicated no significant difference between the near-replicate samples despite very low pooled sample variances $\left(\log _{10} 0.064\right.$ and 0.059 , respectively). This result indicated that, in the sapropels sampled, bacterial 
populations were effectively homogeneous over centimeter scales, and that operator-counting variability remained low.

Total organic carbon (TOC) data were not available for Hole 969B apart from a very few spot observations. A complete data set was, however, obtained from Hole 969A (Fig. 2) 198 m distant from Hole 969B (Emeis, Robertson, Richter, et al., 1996). In general, concentrations of TOC were particularly high, averaging $7.2 \mathrm{wt} \%$ throughout the hole; however, the variance was large, and this high average is probably a sampling artifact because there was a bias to sampling around areas of high interest such as the sapropels. Here many values were over $10 \mathrm{wt} \%$, and a maximum of $30.5 \mathrm{wt} \%$ was recorded at 55.8 mbsf (Emeis, Robertson, Richter, et al., 1996). Cores from Hole 969B were offset with respect to those from Hole 969A, and, despite using mean composite depths (Emeis, Robertson, Richter, et al., 1996) to adjust the TOC data from Hole 969A to fit Hole $969 \mathrm{~B}$, no correlation was observed between total bacterial populations and TOC $(R=0.10 ; N=34)$. This was true even when the TOC data were recalculated as moving averages to remove spikes and allow correlation of bacterial numbers against trends in TOC concentrations. This was unexpected as our previous work has generally demonstrated highly significant correlations between these variables (Parkes et al., 1993; Cragg and Kemp; 1995, Cragg et al., 1995a, 1995b).

It is interesting to note that within the range of TOC concentrations more normally expected, and which we usually encounter in marine sediments $(0-3 \mathrm{wt} \%)$, this data set produced a significant correlation $(R=0.499 ; N=16 ; P<0.05)$ between TOC and bacterial populations. Addition of data with higher TOC concentrations destroyed this relationship, which suggests that at high concentrations, such as those found in sapropels, TOC is effectively present in excess and ceases to be a limiting factor for bacterial population size.

Inorganic interstitial water (IW) chemical data are similarly restricted to cores from Hole 969A. IW sulfate concentrations increase gradually from a bottom-water value of $31.2 \mathrm{mmol} / \mathrm{L}$ to $39.7 \mathrm{mmol} / \mathrm{L}$ at $102 \mathrm{mbsf}$ (Fig. 2), and there is no reason to believe that Hole 969B data would have a profile significantly different from this (H.-J. Brumsack, pers. comm., 1996). At these concentrations, sulfate is in great excess for sulfate-reducing bacteria as concentrations above 3 $\mathrm{mmol} / \mathrm{L}$ are considered nonlimiting (Capone and Kiene, 1988). Sulfur isotope analysis indicates that small amounts of bacterial sulfate reduction occur throughout the core (Böttcher et al., Chap. 29, this volume). Low rates of sulfate reduction would be consistent with the smooth IW sulfate profile, with limited local sulfate removal due to bacterial sulfate reduction being fully, and rapidly, replenished by upward diffusion.

Total sulfur concentrations (in weight percent) very significantly correlate $(R=0.796 ; N=60 ; P \ll<0.002)$ with TOC concentrations (Fig. 2), and most of the sulfur present is in the form of pyrite (Emeis, Robertson, Richter, et al., 1996). As a biological pyrite formation requires temperatures considerably greater than those experienced by these sediments (Raiswell and Al-Biatty, 1992), it is evident that this strong correlation is a reflection of bacterial activity. That bacterial sulfate reduction continues subsequent to burial is supported by the substantial and continuing increase in total sulfur concentrations, mainly as pyrite, with depth to $57.5 \mathrm{mbsf}$ ( 1000\% increase over surface values; Fig. 2).

The total bacterial population profile agrees with a general profile, almost exclusively derived from Pacific Ocean sites, previously calculated by Parkes et al. (1994; Fig. 3), and since augmented by Cragg et al. (1997), given by the expression:

$$
\log _{10} \text { bacterial numbers }=7.94-0.64 \log _{10} \text { depth }(\mathrm{m}) \text {. }
$$

Given the generally high levels of TOC, it might seem surprising that most of the data tend to cluster along the lower prediction limit; however, the majority of such data comes from the depth ranges 9-

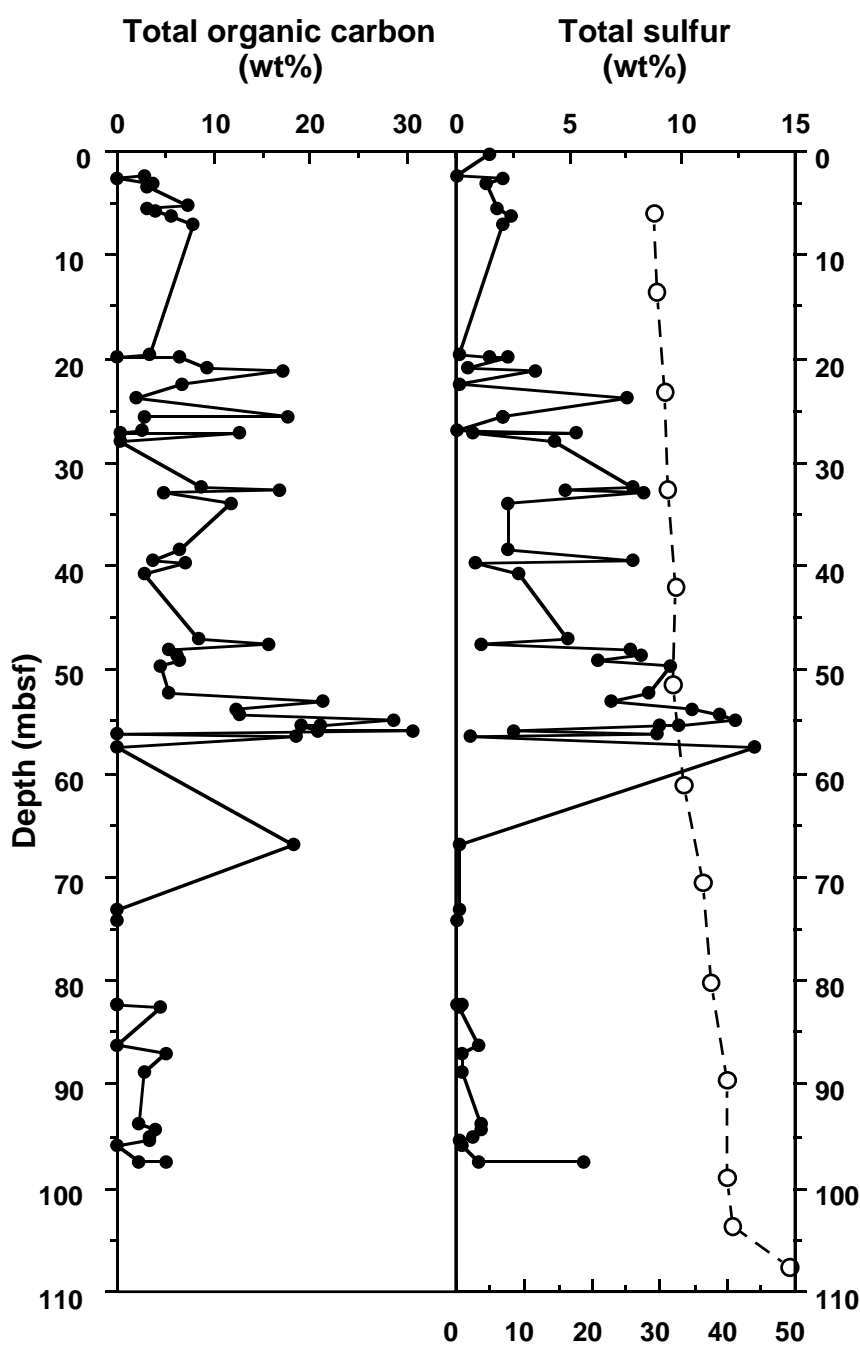

IW Sulfate (mmol/L)

Figure 2. Depth distribution of total organic carbon (solid circles), total sulfur (solid circles), and pore-water sulfate (open circles, dashed line) in Hole 969A, 198 m distant from Hole 969B. (Graph redrawn from Emeis, Robertson, Richter, et al., 1996.)

18 and 55-80 mbsf, associated with red-colored, low organic carbon, oxidized sediments (Emeis, Robertson, Richter, et al., 1996) or from between groups of sapropels where TOC concentrations are also low. Near the surface and where locally high TOC concentrations occur, bacterial population sizes are more generally scattered between the prediction limits. The four highest populations (with respect to the depth/numbers relationship) are the four sapropel samples (Fig. 3). These samples also represent bacterial populations in conditions of particularly high-TOC concentration, although no linear correlation between bacterial concentration and TOC was evident within these four samples. The following data strongly indicates an active and probably growing bacterial population within the sapropels:

1. Bacterial populations considerably, and significantly, greater $(t=6.04,7.15,17.79,15.22 ; N=6 ; P<0.05,<0.05,<<0.005$, $<<0.005$ for $2.72,19.9,45.9$, and 95.79 mbsf, respectively) than those in adjacent nonsapropel sediment layers; 


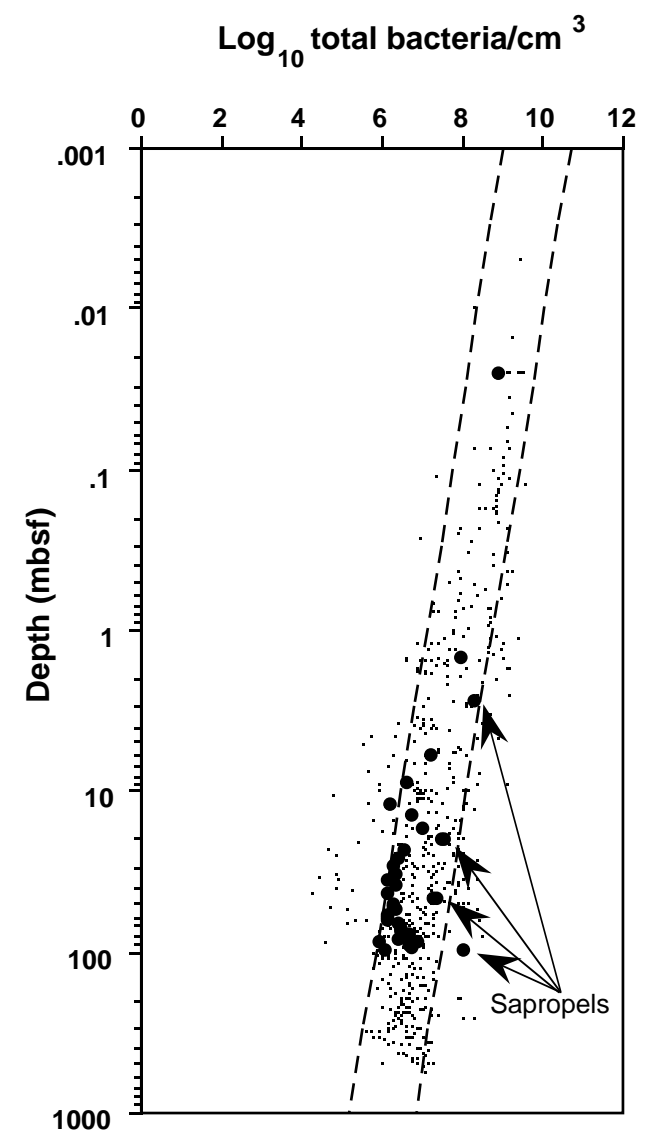

Figure 3. Depth distribution of total bacteria (large solid circles) from Eastern Mediterranean Hole 969B, compared to the distributions of bacterial populations $(\mathrm{n}=550)$ with depth at 15 other sites from seven ODP legs (small solid circles). Heavy slanting dashed lines represent the $95 \%$ prediction limits for the regression line given by the equation: $\log _{10}$ bacterial numbers $=7.94-$ $0.64 \times \log _{10}$ depth (m), from Cragg et al. (1997).

2. The presence of high TOC and abundant electron acceptor (sulfate);

3. Postburial bacterial sulfate reduction activity; and

4. The presence of dividing bacterial cells.

Nevertheless, none of these elevated bacterial populations approached in size the near-surface bacterial population $\left(9.79 \times 10^{8}\right.$ cells $/ \mathrm{cm}^{3}$ near the surface, compared to $1.87 \times 10^{8}, 3.4 \times 10^{7}, 2.2 \times$ $10^{7}$, and $1.02 \times 10^{8}$ cells $/ \mathrm{cm}^{3}$ at $2.72,19.9,46.9$, and $95.89 \mathrm{mbsf}$, respectively), despite the long contact times between buried bacterial population and sapropel organic carbon (to $4.7 \mathrm{Ma}$ ). This suggests that organic carbon within the sapropel layers must be predominantly recalcitrant and only slowly bioavailable or that some other factor becomes limiting within the high-TOC environment of a sapropel. These data add to the expanding body of evidence indicating that bacteria, given favorable conditions, may remain active and grow, albeit relatively slowly, at significant sediment depths and after millions of years of burial (Whelan et al., 1986; Parkes et al., 1990; Cragg et al., 1990, 1995b, 1996; Getliff et al., 1992), and thus explain the presence of significant bacterial populations in deep marine sediment layers.

\section{SUMMARY}

This is the first deep bacteriological investigation of sediments from the Mediterranean Sea. The depth profile of bacterial popula- tions is in good agreement with a general profile derived from a number of Pacific Ocean sites and one Atlantic Ocean site and provides more evidence for a globally distributed deep bacterial community in marine sediments. Bacterial populations in sapropel layers at this site are significantly elevated compared to those in the adjacent sediment. Given the generally very high concentrations of organic carbon and sulfate, increasing concentrations of pyrite with depth, and the significant numbers of bacterial cells either dividing or divided within the sapropels, it is likely that these high bacterial populations are the result of bacterial growth on deeply buried ancient (to $4.7 \mathrm{Ma}$ ) organic matter.

\section{ACKNOWLEDGMENTS}

We would like to thank ODP for allowing us access to samples from Leg 160 and shipboard personnel who assisted in taking samples. We appreciate the useful and constructive criticisms from $\mathbf{M}$. Summit and A.-L. Reysenbach on the initial manuscript. We acknowledge the support and facilities provided by Bristol University, and the Natural Environment Research Council (NERC) for funding this work.

\section{REFERENCES}

Capone, D.G., and Kiene, R.P., 1988. Comparison of microbial dynamics in marine and freshwater sediments: contrasts in anaerobic carbon catabolism. Limnol. Oceanogr., 33:725-749.

Cragg, B.A., 1994. Bacterial profiles in deep sediment layers from the Lau Basin (Site 834). In Hawkins, J., Parson, L., Allan, J., et al., Proc. ODP, Sci. Results, 135: College Station, TX (Ocean Drilling Program), 147150 .

Cragg, B.A., Harvey, S.M., Fry, J.C., Herbert, R.A., and Parkes, R.J., 1992. Bacterial biomass and activity in the deep sediment layers of the Japan Sea, Hole 798B. In Pisciotto, K.A., Ingle, J.C., Jr., von Breymann, M.T., Barron, J., et al., Proc. ODP, Sci. Results., 127/128 (Pt. 1): College Station, TX (Ocean Drilling Program), 761-776.

Cragg, B.A., and Kemp, A.E.S.,1995. Bacterial profiles in deep sediment layers from the Eastern Equatorial Pacific Ocean, Site 851. In Pisias, N.G., Mayer, L.A., Janecek, T.R., Palmer-Julson, A., and van Andel, T.H. (Eds.), Proc. ODP, Sci. Results, 138: College Station, TX (Ocean Drilling Program), 599-604.

Cragg, B.A., Law, K.M., Cramp, A., and Parkes, R.J., 1997. Bacterial profiles in Amazon Fan sediments, Sites 934 and 940. In Flood, R.D., Piper, D.J.W., Klaus, A., and Peterson, L.C. (Eds.), Proc. ODP, Sci. Results, 155: College Station, TX (Ocean Drilling Program), 565-571.

Cragg, B.A., and Parkes, R.J., 1994. Bacterial profiles in hydrothermally active deep sediment layers from Middle Valley (NE Pacific), Sites 857 and 858. In Mottl, M.J., Davis, E.E., Fisher, A.T., and Slack, J.F. (Eds.), Proc. ODP, Sci. Results, 139: College Station, TX (Ocean Drilling Program), 509-516.

Cragg, B.A., Parkes, R.J., Fry, J.C., Herbert, R.A., Wimpenny, J.W.T., and Getliff, J.M., 1990. Bacterial biomass and activity profiles within deep sediment layers. In Suess, E., von Huene, R., et al., Proc. ODP, Sci. Results, 112: College Station, TX (Ocean Drilling Program), 607-619.

Cragg, B.A., Parkes, R.J., Fry, J.C., Weightman, A.J., Maxwell, J.R., Kastner, M., Hovland, M., Whiticar, M.J., Sample, J.C., and Stein, R., 1995a. Bacterial profiles in deep sediments of the Santa Barbara Basin, Site 893. In Kennett, J.P., Baldauf, J.G., and Lyle, M. (Eds.), Proc. ODP, Sci. Results, 146 (Pt. 2): College Station, TX (Ocean Drilling Program), 139144.

Cragg, B.A., Parkes, R.J., Fry, J.C., Weightman, A.J., Rochelle, P.A., and Maxwell, J.R., 1996. Bacterial populations and processes in sediments containing gas hydrates (ODP Leg 146: Cascadia Margin). Earth Planet. Sci. Lett., 139:497-507.

Cragg, B.A., Parkes, R.J., Fry, J.C., Weightman, A.J., Rochelle, P.A., Maxwell, J.R., Kastner, M., Hovland, M., Whiticar, M.J., and Sample, J.C., 1995b. The impact of fluid and gas venting on bacterial populations and processes in sediments from the Cascadia Margin accretionary system (Sites 888-892) and the geochemical consequences. In Carson, B., Westbrook, G.K., Musgrave, R.J., and Suess, E. (Eds.), Proc. ODP, Sci. Results, 146 (Pt 1): College Station, TX (Ocean Drilling Program), 399411. 
Cramp, A., Collins, M.B., and West, R., 1988. Late Pleistocene-Holocene sedimentation in the NW Aegean Sea: a palaeoclimatic palaeoceanographic reconstruction. Palaeogeogr., Palaeoclimatol., Palaeoecol., 68:61-77.

Dewey, J.F., Pitman, W.C., Ryan, W.B.F., and Bonin, J., 1973. Plate tectonics and the evolution of the Alpine system. Geol. Soc. Am. Bull., 84:31373180 .

Emeis, K.-C., Robertson, A.H.F., Richter, C., et al., 1996. Proc. ODP, Init. Repts., 160: College Station, TX (Ocean Drilling Program).

Fry, J.C., 1988. Determination of biomass. In Austin, B. (Ed.), Methods in Aquatic Bacteriology: Chichester (Wiley), 27-72.

Furnes, H., Thorseth, I.H., Tumyr, O., Torsvik, T., and Fisk, M.R., 1996. Microbial activity in the alteration of glass from pillow lavas from Hole 896A. In Alt, J.C., Kinoshita, H., Stokking, L.B., and Michael, P.J. (Eds.), Proc. ODP, Sci. Results, 148: College Station, TX (Ocean Drilling Program), 191-206.

Getliff, J.M., Fry, J.C., Cragg, B.A., and Parkes, R.J., 1992. The potential for bacteria growth in deep sediment layers of the Japan Sea, Hole 798B?Leg 128. In Pisciotto, K.A., Ingle, J.C., Jr., von Breymann, M.T., Barron, J., et al., Proc. ODP, Sci. Results, 127/128 (Pt. 1): College Station, TX (Ocean Drilling Program), 755-760.

Giovannoni, S.J., Fisk, M.R., Mullins, T.D., and Furnes, H., 1996. Genetic evidence for endolithic microbial life colonizing basaltic glass/seawater interfaces. In Alt, J.C., Kinoshita, H., Stokking, L.B., and Michael, P.J. (Eds.), Proc. ODP, Sci. Results, 148: College Station, TX (Ocean Drilling Program), 207-214.

Goulder, R., 1977. Attached and free bacteria in an estuary with abundant suspended solids. J. Appl. Bacteriol., 43:399-405.

Jørgensen, B.B., 1983. Processes at the sediment/water interface. In Bolin, B., and Cook, R.B. (Eds.), The Major Biogeochemical Cycles and Their Interactions: Chichester (Wiley), 477-515.

Jørgensen, B.B., Bang, M., Blackburn, T.H., 1990. Anaerobic mineralization in marine sediments from the Baltic Sea-North Sea transition. Mar. Ecol. Prog. Ser., 59:39-54.

Kirchman, D., Sigda, J., Kapuscinski, R., and Mitchell, R., 1982. Statistical analysis of the direct count method for enumerating bacteria. Appl. Environ. Microbiol., 44:376-382.

Krumbein, W.E., 1983. Microbial Geochemistry: Oxford (Blackwell).

Müller, P.J., and Suess, E., 1979. Productivity, sedimentation rate, and sedimentary organic matter in the oceans, I. Organic carbon preservation. Deep-Sea Res. Part A, 26:1347-1362.
Novitsky, J.A., and Karl, D.M., 1986. Characterization of microbial activity in the surface layers of a coastal sub-tropical sediment. Mar. Ecol. Prog. Ser., 28:49-55.

Parkes, R.J., Cragg, B.A., Bale, S.J., and Fry, J.C., 1995. A combined ecological and physiological approach to studying sulphate reduction within deep marine sediment layers. J. Microbiol. Methods, 23:235-249.

Parkes, R.J., Cragg, B.A., Bale, S.J., Getliff, J.M., Goodman, K., Rochelle, P.A., Fry, J.C., Weightman, A.J., and Harvey, S.M., 1994. A deep bacterial biosphere in Pacific Ocean sediments. Nature, 371:410-413.

Parkes, R.J., Cragg, B.A., Fry, J.C., Herbert, R.A., and Wimpenny, J.W.T., 1990. Bacterial biomass and activity in deep sediment layers from the Peru margin. Philos. Trans. R. Soc. London A, 331:139-153.

Parkes, R.J., Cragg, B.A., Getliff, J.M., Harvey, S.M., Fry, J.C., Lewis, C.A., and Rowland, S.J., 1993. A quantitative study of microbial decomposition of biopolymers in Recent sediments from the Peru Margin. Mar. Geol., 113:55-66.

Raiswell, R., and Al-Biatty, H.J., 1992. Depositional and diagenetic C-S-Fe signatures and the potential of shales to generate metal-rich fluids. In Schidlowski, M., et al. (Eds.), Early Organic Evolution: Implications for Mineral and Energy Resources: Berlin (Springer-Verlag).

Rohling, E.J., 1994. Review and new aspects concerning the formation of eastern Mediterranean sapropels. Mar. Geol., 122:1-28.

Tarafa, M.E., Whelan, J.K., Oremland, R.S., and Smith, R.L., 1987. Evidence of microbiological activity in Leg 95 (New Jersey Transect) sediments. In Poag, C.W., Watts, A.B., et al., Init. Repts. DSDP, 95: Washington (U.S. Govt. Printing Office), 635-640.

Vergnaud-Grazzini, C., Devaux, M., and Znaidi, J., 1986. Stable isotope "anomalies" in Mediterranean Pleistocene records. Mar. Micropaleontol., 10:35-69.

Whelan, J.K., Oremland, R., Tarafa, M., Smith, R., Howarth, R., and Lee, C., 1986. Evidence for sulfate-reducing and methane producing microorganisms in sediments from Sites 618, 619, and 622. In Bouma, A.H., Coleman, J.M., Meyer, A.W., et al., Init. Repts. DSDP, 96: Washington (U.S. Govt. Printing Office), 767-775.

Date of initial receipt: 5 February 1997

Date of acceptance: 9 June 1997

Ms 160SR-069 